\title{
SOMATIC EMBRYOGENESIS OF SELECTED CONIFEROUS TREE SPECIES OF THE GENERA PICEA, ABIES AND LARIX
}

\author{
KRYSTYNA SZCZYGIEt ${ }^{1}$, TERESA HAZUBSKA-PRZYBYŁ ${ }^{2}$, \\ KRYSTYNA BOJARCZUK ${ }^{2}$ \\ ${ }^{1}$ Forest Research Institute \\ Department of Genetics and Physiology of Forest Tree \\ Bitwy Warszawskiej 1920 roku 3, 00-973 Warszawa, Poland \\ 2 Polish Academy of Sciences, Institute of Dendrology \\ Parkowa 5, 62-035, Kórnik, Poland \\ e-mail: bojark@man.poznan.pl
}

(Received: April 12, 2006. Accepted: June 21, 2006)

\begin{abstract}
Experiments on somatic embryogenesis in selected spruce, fir and larch species were performed to determine if this method of micropropagation enables production of quality seedlings for forest nurseries. High frequencies of embryogenic callus in spruce (23-31\%) and fir (29\%) were achieved when mature zygotic embryos were used as explants, while in larches (36\%) only when megagametophytes (endosperms with immature embryos) were used. The possibility of somatic embryogenesis initiation also from somatic embryos (resulting in secondary and third generation of embryogenic callus) indicate high efficiency of this method of micropropagation. The best results at all stages of somatic embryogenesis (good proliferation of embryogenic callus, high rate of embryo regeneration and their survival) were obtained for Norway spruce, European larch and some hybrid larches.
\end{abstract}

KEY WORDS: micropropagation, in vitro culture, ex vitro, development, media, hormones, spruce, larch, fir.

\section{INTRODUCTION}

Somatic embryogenesis is a morphogenetic process, which enables formation and development of embryos from somatic (vegetative) cells, without fertilization. This process can be used for micropropagation of trees, and its main advantage is the high rate of regeneration and possibility of production of large numbers of plantlets from a small fragment of donor tissue (an explant). In this way, plants homogeneous genetically and morphologically with the selected donor plant can be produced (plant cloning). Somatic embryogenesis can be also used for long-term storage of plant material in the form of embryogenic callus or somatic embryos in liquid nitrogen (cryopreservation). However, somatic embryogenesis is sometimes ineffective because of various problems. For example, some species and some genotypes within species do not show the ability to produce embryogenic callus. In order to produce quality seedlings by means of somatic embryogenesis, it is necessary to determine experimentally the optimum conditions, which would enable production of well-developed somatic seedlings from a many valuable genotypes.

The first successful attempts of Norway spruce propagation by means of somatic embryogenesis were made by
Hakman et al. (1985) and Chalupa (1985). Research on silver fir and European larch micropropagation with use of this method were also started then (1985-1986), but the first satisfactory results were reported for European larch in 1989-1990 (Klimaszewska 1989; von Aderkas et al. 1990), whereas for silver fir as late as in 1995 (Hristoforoglu et al. 1995).

At the Forestry Research Institute in Warsaw and at the Institute of Dendrology in Kórnik, intensive research is conducted on somatic embryogenesis of coniferous trees, to enable its use for efficient micropropagation of selected trees for forestry and horticulture. In this study we aimed to verify the usefulness of this method for micropropagation of selected Picea, Abies and Larix species.

\section{MATERIAL AND METHODS}

\section{Plant material}

Sources of explants for our experiments were mature and immature zygotic embryos from seeds of various provenances of Norway spruce (Picea abies (L.) Karst.), Serbian spruce $(P$. omorika (Pančic) Purk.), Colorado blue spruce (P. pungens Beissn. 'Glauca'), Brewer's spruce ( $P$. brewe- 
riana S. Wats.), silver fir (Abies alba Mill.), European larch (Larix decidua Mill., from Poland) and hybrids between European and Japanese larch (L. × leptoeuropaea Dengler) - lines of embryogenic callus from France (Institut National de la Recherche Agronomique, Orleans, France). The seeds originated from seed orchards, from samples representing various populations, and from individual maternal trees (paternal trees unknown). In the experiments, each sample was represented by 60-100 zygotic embryos. To initiate embryogenic callus from Serbian, Norway and Colorado blue spruce, European larch, and silver fir, some attempts were also made to use immature embryos with endosperm (megagametophyte) as explants. Also secondary and third generations of callus were produced from somatic embryos at the globular or cotyledonary stage (spruces and larches) and cotyledons or hypocotyls of 1-month-old somatic spruce seedlings.

\section{Media}

At all stages of somatic embryogenesis following basal media were used: for spruces the BM-3 medium (Gupta and Durzan 1986) and 50\% LM medium (Litvay et al. 1985); for larches the MSG medium (Becwar et al. 1990); and for fir the MCM medium (Bornman and Jansson 1981 after Hristoforoglu et al. 1995). During embryogenic callus initiation, the above-mentioned BM-3 medium and the $\mathrm{SH}$ medium (Schenck and Hildebrandt 1972) were used additionally for fir. At the germination stage also half strength MS medium (Murashige and Skoog 1962) was applied. Depending on stage of somatic embryogenesis, the media were supplemented or not with appropriate growth hormones and sugars (sucrose alone or maltose), as described below. Medium $\mathrm{pH}$ was adjusted to $5.8 \pm 0.1$. The media were solidified on Petri dishes with phytagel (4 g/l) and sterilized in an autoclave at $121^{\circ} \mathrm{C}$ for $20 \mathrm{~min}$ at a pressure of 1 atmosphere. Solutions of \pm cis-trans ABA, IBA, NAA and L-glutamine (Sigma) were filter sterilized and added to the autoclaved, cooled medium.

\section{Initiation of somatic embryogenesis}

To induce embryogenic callus, the media for the studied spruce species and larch were supplemented with 9 $\mu \mathrm{M}$ 2.4-D, and 4.4 $\mu \mathrm{M}$ BAP, additional for larches was added $4.5 \mu \mathrm{M}$ zeatin. Embryogenic callus of silver fir was initiated by placing mature zygotic embryos on the basal media MCM and BM-3, supplemented with $4.4 \mu \mathrm{M}$ BAP or $2.2 \mu \mathrm{M}$ BAP and $2.3 \mu \mathrm{M}$ kinetin, while immature zygotic embryos on the $\mathrm{SH}$ medium, supplemented with 4.4 $\mu \mathrm{M}$ BAP and the MCM medium with $2.2 \mu \mathrm{M}$ BAP and 2.3 $\mu \mathrm{M}$ kinetin. All the initiation media were supplemented with sucrose (10-30 g/l).

\section{Proliferation of embryogenic callus}

After 4-6 weeks culture of the explants, the produced callus was transferred onto proliferation medium. For spruces and larches, the basal medium was supplemented with $9 \mu \mathrm{M} 2.4-\mathrm{D}$ with $2.2 \mu \mathrm{M}$ BAP or $9 \mu \mathrm{M}$ NAA, $9 \mu \mathrm{M}$ Picloram with $2.2 \mu \mathrm{M}$ BAP and sucrose $(20 \mathrm{~g} / \mathrm{l})$. For fir, the MCM medium was supplemented with $2.2 \mu \mathrm{M}$ BAP, 2.3 $\mu \mathrm{M}$ kinetin and $0.2 \mu \mathrm{M}$ 2.4-D. Callus was divided and transferred to fresh media every 2-3 weeks. At both phases (initiation and proliferation of callus), the cultures were kept in darkness, at $25^{\circ} \mathrm{C}$.

\section{Maturation of somatic embryos}

The stage of somatic embryogenesis was composed of two phases: (1) callus culture for one week on the basal medium supplemented with activated charcoal (10 g/l), but without growth hormones (Becwar et al. 1987); and (2) culture on the basal medium supplemented with 10-60 $\mu \mathrm{M}$ ABA and $1 \mu \mathrm{M}$ IBA.

At this stage, spruce and larch cultures were maintained under $16 \mathrm{~h}$ photoperiod, at a light intensity $25-30 \mu \mathrm{E} \mathrm{m} \mathrm{m}^{-2} \mathrm{~s}^{-1}$, at $25^{\circ} \mathrm{C}$, while fir cultures were kept in darkness. Depending on tree species, this stage lasted 4-10 weeks.

After the experiments, callus pieces were weighed and next placed directly on the solidified medium or on a paper filter lying on the medium. In both variants, the number of developed somatic embryos were calculated (per $1 \mathrm{~g}$ fresh weight of embryogenic callus).

\section{Germination and conversion of somatic embryos into plantlets and adaptation to ex vitro conditions}

Somatic embryos at the cotyledonary stage were isolated (on the basis of their morphology) and placed on the basal medium or half strength MS medium without growth hormones but with activated charcoal $(5 \mathrm{~g} / \mathrm{l})$. Before placing on the germination medium, somatic embryos of Norway spruce and silver fir were slightly dried (for 3-4 weeks) at high relative humidity $95-97 \%$ - partial drying, in the dark at $25^{\circ} \mathrm{C}$ (Roberts et al. 1990). The germination stage started with 14 days in darkness. Next, the cultures were kept in dim light (15-20 $\left.\mu \mathrm{E} \mathrm{m}^{-2} \mathrm{~s}^{-1}\right)$ for another 14 days. After the dark and the light periods, calculated the percentage of embryos with primary roots (radicles). Afterwards, embryos were cultured for another month on media without growth hormones. The conversion rate of somatic embryos into plantlets was assessed on the basis of development of roots and the first needles.

Two methods of adaptation of somatic seedlings to natural conditions were compared: (a) transplantation to sterile Jiffy peat pots, and (b) transplantation to a substrate composed of a mixture of peat with perlite or vermiculite (v:v 1:1). For 1-2 months, the plantlets were cultured at high relative humidity (80-90\%) under low light intensity, in phytotron. Next, relative humidity was lowered to 60$-70 \%$ and light intensity was increased gradually. Finally, the plantlets were moved to a greenhouse. The production cycle of a somatic seedling usually lasted 8-12 months.

The analysis of variance and Tukey test were used to study the differences between respective variants (significance level $\alpha=0.05$ ). The data in figures are means \pm standard error.

\section{RESULTS}

\section{Initiation of embryogenic callus}

The experiments were based mainly on explants from mature seeds, i.e. mature zygotic embryos (mZE), but some attempts were made also with the use of immature zygotic embryos (iZE) or megagametophytes with immature embryos (M) (Table 1). For mature zygotic embryos $(\mathrm{mZE})$ isolated from seeds deriving from various populations and stored for 2-6 years, the frequency of embryogenic callus initiation in Norway spruce reached $0-31.4 \%$ (over 5500 embryos were used). Slightly lower frequencies 
TABLE 1. Frequency of embryogenic callus initiation from various explant types in all studied coniferous species.

\begin{tabular}{|c|c|c|c|}
\hline Species & Explant type & Basal medium & Frequency of callus initiation (\%) \\
\hline & $\mathrm{mZE}$ & BM-3 & $0-31.4$ \\
\hline \multirow[t]{5}{*}{ Norway spruce (Picea abies) } & iZE & & $0-23.0$ \\
\hline & M & & $0-23.3$ \\
\hline & SE & & $20.0-24.0$ \\
\hline & $\mathrm{C}$ & & $0-23.5$ \\
\hline & $\mathrm{H}$ & & $0-16.7$ \\
\hline \multirow[t]{3}{*}{ Serbian spruce $(P$. omorika) } & $\mathrm{mZE}$ & & $0-23.8$ \\
\hline & iZE & $50 \% \mathrm{LM}$ & $0-10.0$ \\
\hline & SE & & $0-11.9$ \\
\hline \multirow[t]{2}{*}{ Colorado blue spruce ( $P$. pungens 'Glauca') } & $\mathrm{mZE}$ & & $0-23.8$ \\
\hline & iZE & (BM-3) & 0 \\
\hline Brewer's spruce $(P$. breweriana $)$ & $\mathrm{mZE}$ & & $0-10.8$ \\
\hline \multirow[t]{4}{*}{ European larch (Larix decidua) } & mZE & MSG & 0 \\
\hline & iZE & & $0-8.6$ \\
\hline & M & & $0-35.7$ \\
\hline & SE & & $40.0-80.0$ \\
\hline \multirow[t]{3}{*}{ Silver fir (Abies alba) } & mZE & MCM & $1.8-29.4$ \\
\hline & iZE & & $0-10.4$ \\
\hline & M & & $0-2.9$ \\
\hline
\end{tabular}

mZE - mature zygotic embryo; iZE - immature zygotic embryo; M - megagametophyte (endosperm with immature zygotic embryo); SE - somatic embryo; $\mathrm{C}$ and $\mathrm{H}$ - cotyledons and hypocotyls of 1-month-old somatic seedlings.

Media: BM-3 (Gupta and Durzan 1986), LM (Litvay et al. 1985), MSG (Becwar et al. 1990), MCM (Bornman and Jansson 1981 after Hristoforoglu et al. 1995).

were obtained in Serbian and Colorado blue spruce (0$-23.8 \%$ each), whereas in Brewer's spruce, embryogenic callus developed poorly (0-10.8\%). Efficient initiation of embryogenic tissue from mature zygotic embryos was recorded in silver fir (1.8-29.4\%). No embryogenic callus from mature zygotic embryos of European larch (although over 2000 embryos of 10 provenances were used) was achieved. However, satisfactory frequencies (0-35.7\%) were obtained with the use as explants of megagametophytes with immature embryos (M) and lower frequencies (0$-8.6 \%$ ) from immature zygotic embryos with well-developed cotyledons (iZE). When immature zygotic embryos were used (iZE), embryogenic callus was produced by 0 $-23 \%$ of embryos in Norway spruce, $0-10 \%$ in Serbian spruce, and $0-10.4 \%$ in silver fir.

In experiments on embryogenic callus initiation, extensive possibilities of utilization of secondary explants, such as somatic embryos (SE) at the globular or cotyledonary stage and fragments of somatic seedlings: cotyledons (C) and hypocotyls $(\mathrm{H})$ were observed. Initiation of secondary callus of Norway spruce from $24 \%$ of globular embryos, $20 \%$ of cotyledonary embryos, and from fragments of 1-month-old somatic seedlings $(23.5 \%$ from cotyledons and $16.7 \%$ from hypocotyls) was successful. Secondary callus was also produced by $11.9 \%$ of somatic embryos of Serbian spruce. In larches, high frequencies of initiation of secondary and third callus generation (40-80\%) were obtained by using globular and cotyledonary somatic embryos.

These results indicate a strong influence of explant origin on frequency of embryogenic callus initiation in the studied tree species. Significant differences in its frequency were observed between species, but also within species: between populations and between progenies of individual maternal trees. As an example, Figure 1 presents frequen-

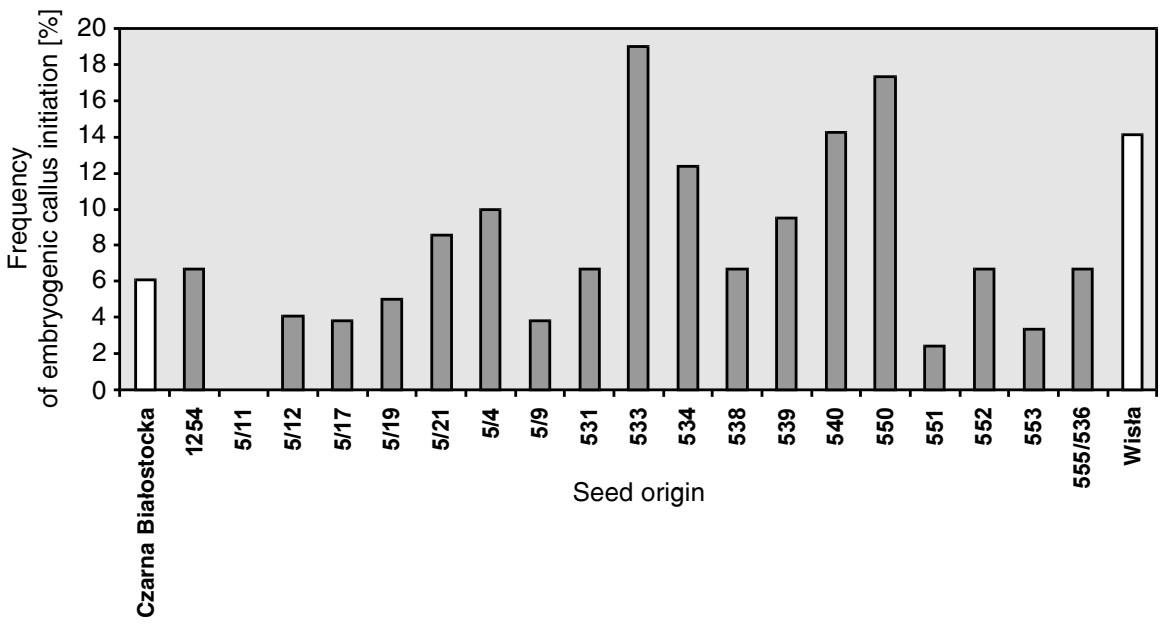

Fig. 1. Embryogenic callus initiation in mature zygotic embryos of Norway spruce (Picea abies) from 19 trees from the Sudety Mts (grey columns, tree number) and of populations Czarna Białostocka and Wisła (white columns). 
TABLE 2. Survival rate of embryogenic lines of the some studied spruce species during culture on media (BM-3, 50\% LM) supplemented with $9 \mu$ M 2.4-D and $2.25 \mu \mathrm{M}$ BA.

\begin{tabular}{lcccc}
\hline & No. of & & & \multicolumn{2}{c}{ Survival rate $(\%)$} \\
\cline { 3 - 5 } Spruce species & embryogenic lines & 6 months & 12 months & 24 months \\
\hline Norway (Picea abies) & 22 & 40.9 & 31.8 & 9.1 \\
Serbian (P. omorika) & 214 & 22.4 & 5.6 & 0.5 \\
Colorado blue (P. pungens 'Glauca') & 7 & 14.3 & 0.5 & 0 \\
Brewer's (P. breweriana) & 88 & 5.7 & 0 & 0 \\
\hline
\end{tabular}

cies of embryogenic callus initiation from mature zygotic embryos of Norway spruce for 19 trees from the Sudety Mountains (SW Poland) and for two populations: Czarna Białostocka (NE Poland) and Wisła (S Poland).

\section{Proliferation and development of embryogenic tissue}

Embryogenic tissues of individual tree species differed in survival rate and potential for further proliferation. The highest survival rates were recorded for embryogenic callus of Norway spruce, which was characterized by a high viability and long-term growth (some lines lived for 6-8 years). From other spruce species, only some embryogenic tissues of Serbian spruce continued to grow for over 24 months. Callus of Colorado blue and Brewer's spruce turned brown and died already after several months of culture (Table 2).

After 2 years of silver fir culture, only $36 \%$ of the initiated callus lines were still proliferating. In the case of larches, $87.5 \%$ of callus lines continued to grow after 7 months, but only $45.8 \%$ did after 12 months. Also among secondary callus lines, only $58.8 \%$ were still growing after 9 months, while the others turned brown and died.

Medium composition was another factor markedly affecting the initiation and growth rate of embryogenic callus. The development of embryogenic tissue in spruces and larches has been positively influenced by a decrease in sucrose content of the basal medium (from $30 \mathrm{~g} / \mathrm{l}$ to $20 \mathrm{~g} / \mathrm{l}$ ) and in BAP content (from $4.4 \mu \mathrm{M}$ to $2.2 \mu \mathrm{M}$ ). Good results of callus growth in Norway spruce and fir were recorded when hydrolysate casein (1-1.5 g/l) was added to the medium. In Serbian spruce, however, this treatment had a negative influence on embryogenic callus growth. In this species, the best results were observed when $9 \mu \mathrm{M}$ Pikloram and $2.25 \mu \mathrm{M}$ BA were added to the medium (Fig. 2).

\section{Maturation of somatic embryos}

The experiments showed that numbers of regenerated mature somatic embryos in the studied tree taxa depended on explant genotype (Figs 3 and 4). The influence of embryogenic tissue culture duration (i.e. duration of contact with $\mathrm{ABA}$ ) on numbers of produced somatic embryos in Norway spruce was analyzed (Fig. 4). No significant differences were observed in total number of embryos nor in number of cotyledonary embryos between week 4 and week 5 of callus culture, although the number of cotyledonary embryos was slightly higher in week 5 .

Modification of the basal BM-3 medium by increasing the concentration of casein hydrolysate to $1 \mathrm{~g} / \mathrm{l}$ and addition of $20-40 \mu \mathrm{M}$ ABA (depending on genotype) with 1 $\mu \mathrm{M}$ IBA, as well as culture in light for 5 weeks, created optimum conditions for somatic embryo maturation in most callus lines of the studied Norway spruce lines. Depending on spruce genotype, 100-400 embryos were deve-

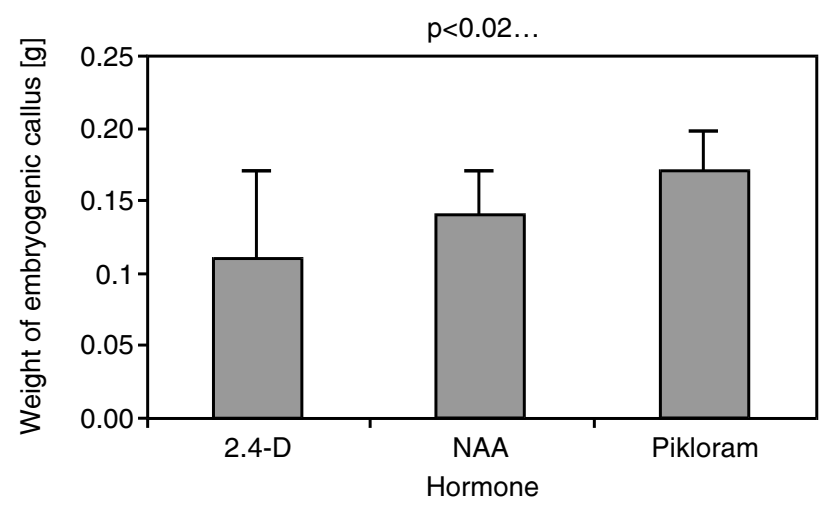

Fig. 2. Proliferation of embryogenic callus of Serbian spruce (Picea omorika) cultured on $50 \%$ LM medium with $2.25 \mu \mathrm{M}$ BA and $9 \mu \mathrm{M}$ 2.4-D, 9 $\mu \mathrm{M}$ NAA and $9 \mu \mathrm{M}$ Picloram.

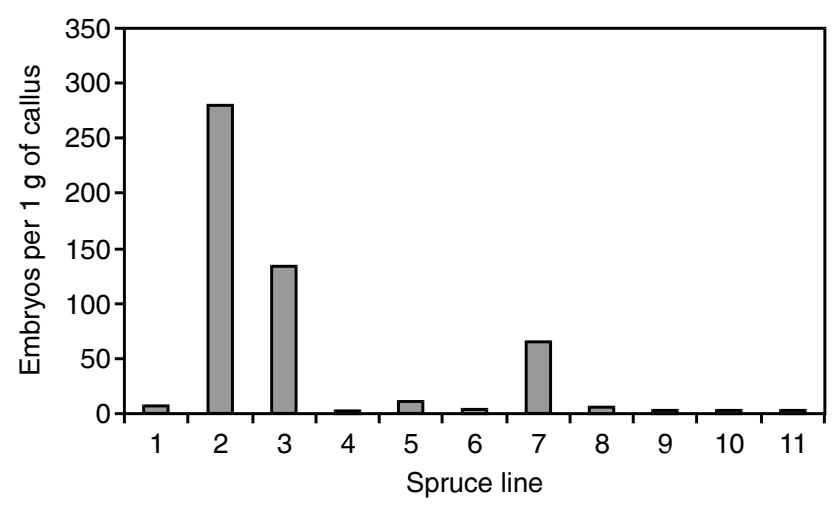

Fig. 3. Number of somatic embryos per $1 \mathrm{~g}$ (fresh weight) of embryogenic callus in selected embryogenic lines deriving from individual zygotic embryos of Serbian spruce (Picea omorika), cultured on the BM-3 medium with $20 \mu \mathrm{M}$ ABA and $1 \mu \mathrm{M}$ BA.

loped per $1 \mathrm{~g}$ (fresh weight) of callus, and 80-200 of them reached the cotyledonary stage (Fig. 4). In other experiments, using secondary callus (somatic embryos as a source of explants), even 600-1200 embryos per $1 \mathrm{~g}$ of callus were produced by many explants.

Numbers of regenerated somatic embryos (total and cotyledonary) in 10 embryogenic callus lines of larches also indicate to a strong influence of genotype on the process of somatic embryogenesis (Fig. 5). Among the callus lines of hybrid larch (L. $\times$ leptoeuropaea, 4 French lines), the highest potential for regeneration of somatic embryos was recorded for line 7 (originally marked as 69.18), on average about 1500 embryos, including 1100 cotyledonary embryos. Among the callus lines of European larch (6 Polish lines), the best results were obtained for line 5 (from Młynary in N Poland), on average 949 embryos, including 226 at cotyledonary stage (Fig. 5). 

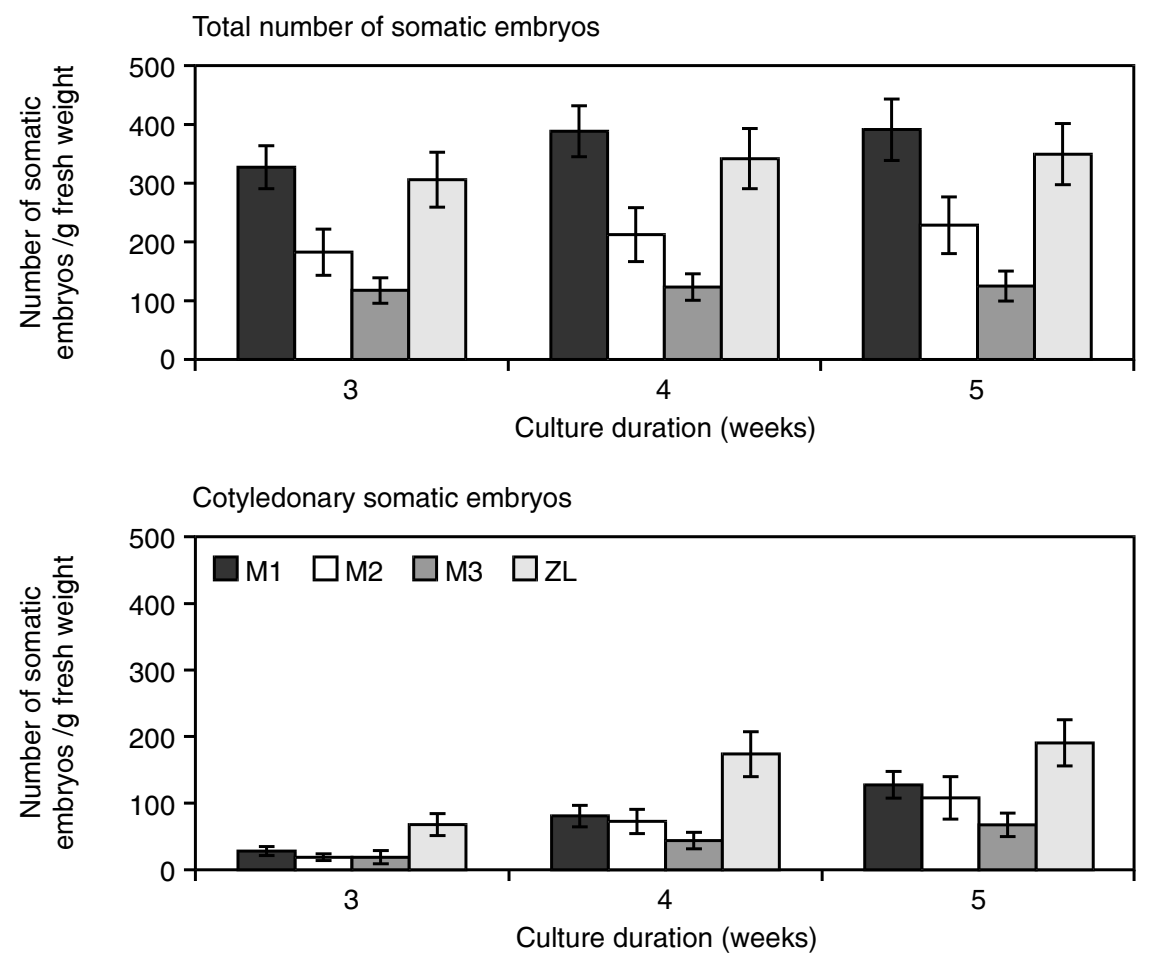

Fig. 4. Effect of explant genotype and duration of culture on maturation medium (with $20 \mu \mathrm{M} \mathrm{ABA}$ and $1 \mu \mathrm{M}$ IBA) on number of somatic embryos per $1 \mathrm{~g}$ (fresh weight) of embryogenic callus in Norway spruce (Picea abies). Lines: M1 - callus origin Istebna $\mathrm{Bu}$ kowiec (deriving from mature zygotic embryo); M2 and M3 - calli second generation, origin Istebna Bukowiec (deriving from somatic embryos); ZL - callus origin Zwierzyniec Lubelski (mature zygotic embryo as an explant).
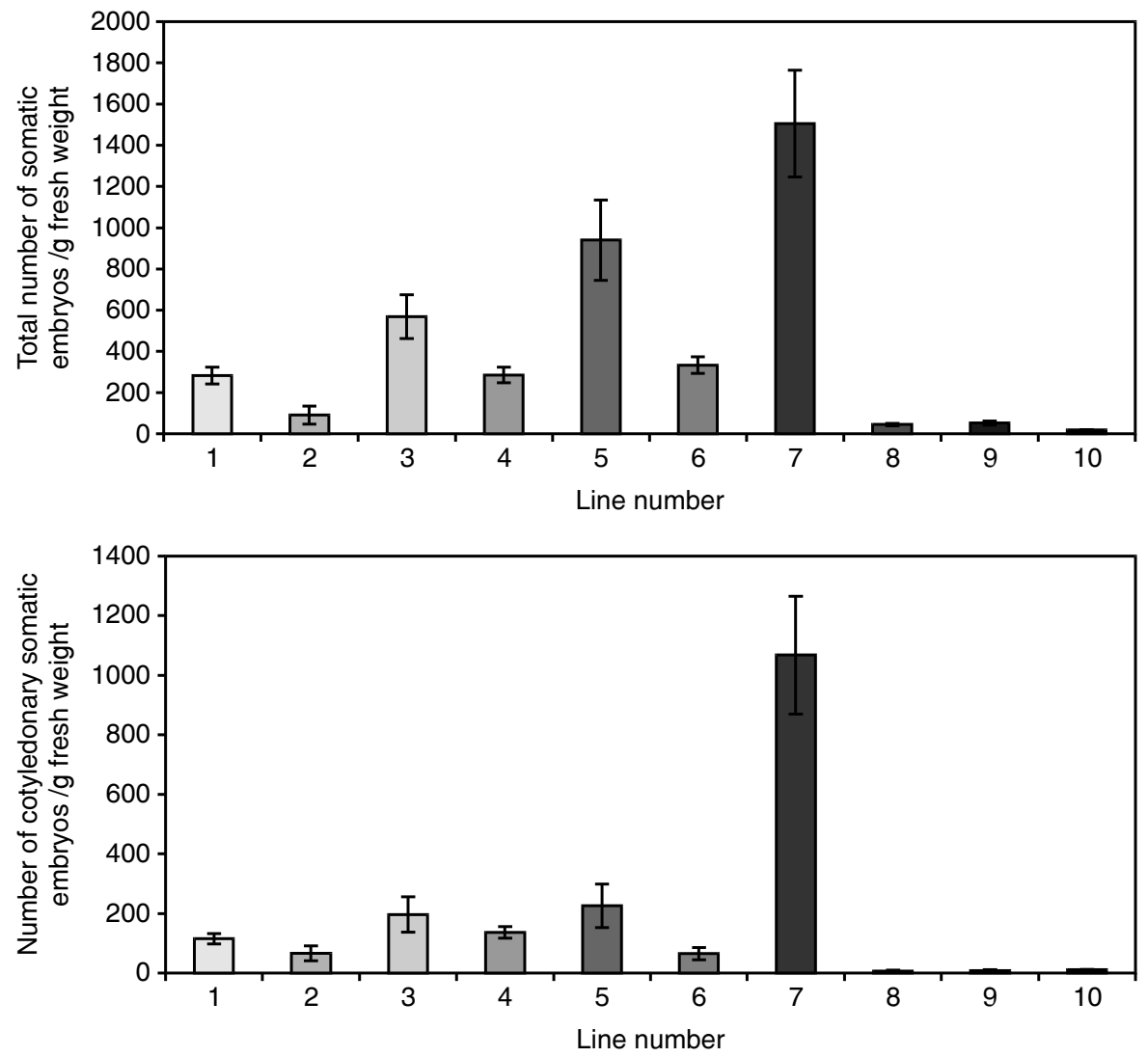

Fig. 5. Effect of explant genotype on number of somatic embryos of larches per $1 \mathrm{~g}$ (fresh weight) of embryogenic callus cultured on the basal medium with $60 \mu \mathrm{M}$ ABA and 1 uM IBA. Lines: 1-6 - European larch (Larix decidua) from Poland; 7-10 - hybrid larch (L. $\times$ leptoeuropaea), callus from France (69.18, F80, C1, H18C).

Silver fir was characterized by a low potential for embryo regeneration. The best effects were observed in most fir lines if the cultures were kept for 6-10 weeks in darkness on the basal medium (MCM) with $20 \mu \mathrm{M}$ ABA and $1 \mu \mathrm{M}$ IBA. Anyway, numbers of somatic embryos per $1 \mathrm{~g}$ (fresh weight) of callus were low as compared to the other studied tree species. Only one line (deriving from seeds from the Lesko in SE Poland) was distinguished by a high effi- ciency of somatic embryogenesis (on average 242 embryos, including 108 cotyledonary embryos).

Germination, conversion of somatic embryos and adaptation of plantlets to ex vitro conditions

A slight drying of somatic embryos before placing them on a germination medium improved their germination and future conversion into plantlets in Norway spruce and fir. 


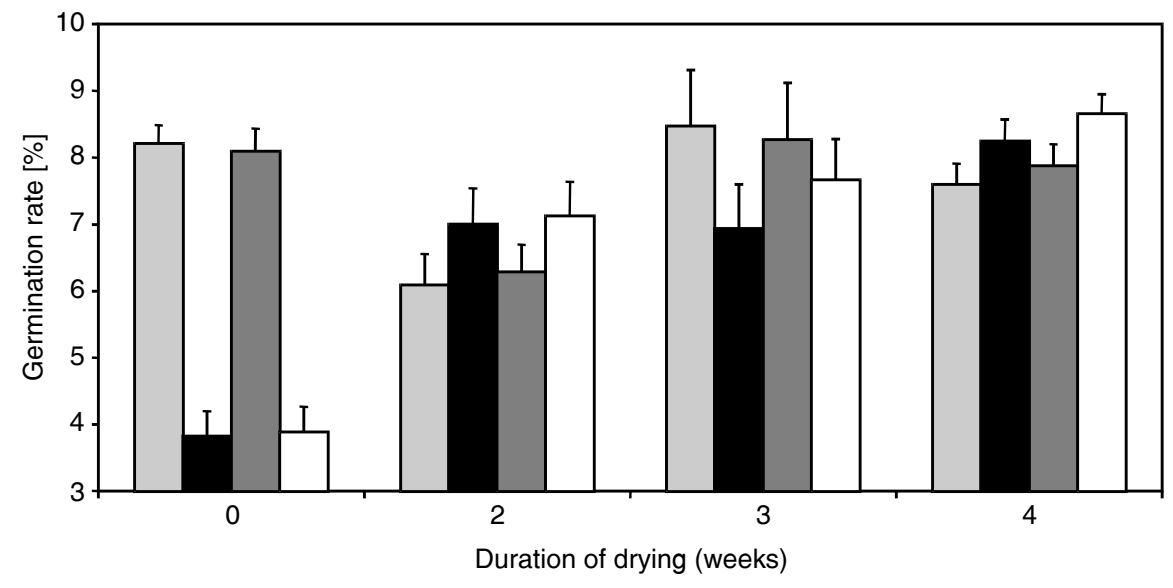

$\square$ of embryos with cotyledons after 14 days

\% of embryos with cotyledons after 28 days $\quad \square \%$ of embryos with roots after 28 days

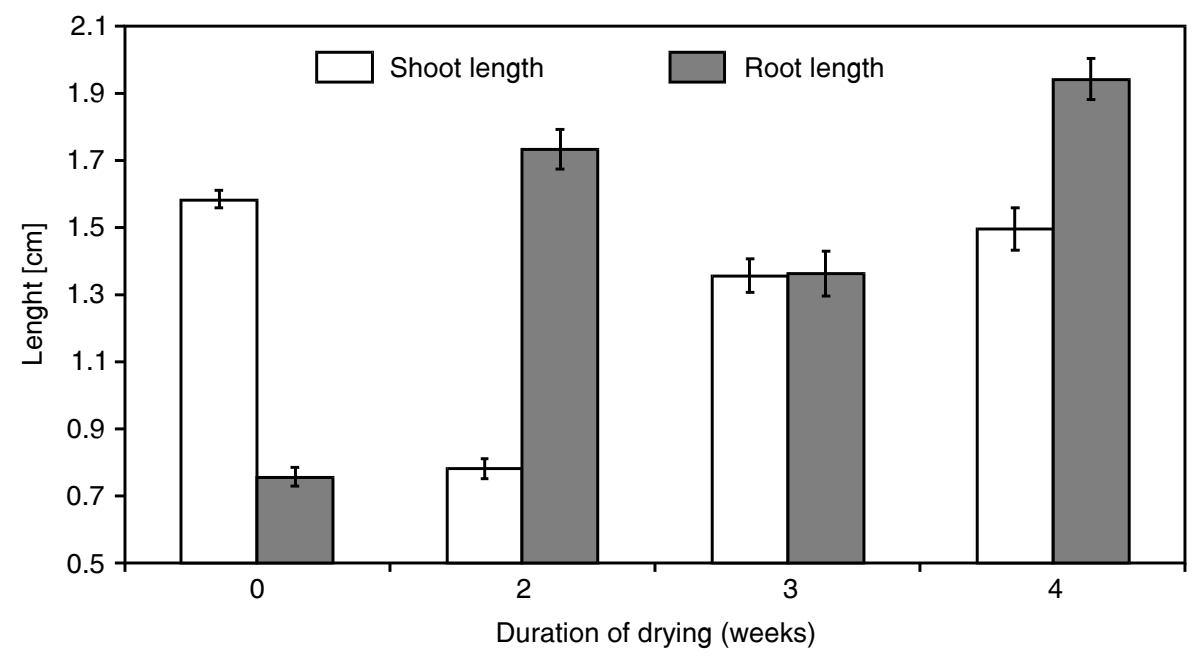

Fig. 6. Influence of partial drying Norway spruce (Picea abies) somatic embryos on their germination.
Partial drying for 3-4 weeks of Norway spruce embryos increased the germination rate, as compared to embryos that were not dried (Fig. 6). The drying phase had also a favourable influence on growth and development of 1-month-old plantlets, as it resulted in more synchronous development of roots and shoots and in significantly increased of root and shoot length in 1-month-old plantlets of Norway spruce (Fig. 7). In silver fir, somatic embryos showed high germination rates after 3 weeks of drying (69-79\%). However, embryos of some taxa had high conversion rates without the drying phase (e.g. 70-100\% in larches and 60-100\% in Serbian spruce).

The adaptation of somatic seedlings of Norway spruce, Serbian spruce, and silver fir to growth and development under ex vitro conditions (after transplantation from the agar medium and sterile conditions to a soil and natural conditions) was gradual. The plantlets were initially transferred to a phytotron, next to a greenhouse, and finally to a nursery. Somatic seedlings of these species require special care at the early stages of growth. After adaptation in a greenhouse, the somatic seedlings of Norway spruce were grown in the nursery of the Forest Research Institute in Warsaw for a few growing seasons, showed proper growth and development.
Somatic seedlings of European larch (from Poland) and hybrid larch (from France) showed a great adaptability to growth and development under ex vitro conditions. During the first growing season the survival rate was $30-50 \%$ in European larch and 50-100\% in the hybrid larch. This indicates the possibility of large-scale production of somatic larch seedlings.

\section{DISCUSSION}

\section{Embryogenic callus initiation}

For initiation of embryogenic tissue in spruce, researchers have used immature (Hakman et al. 1985) and mature zygotic embryos (Gupta and Durzan 1986; von Arnold 1987; Adams et al. 1994; Hazubska and Szczygieł 2003) or cotyledons and hypocotyls of germinating zygotic or somatic embryos and needles (Lelu et al. 1987; Lelu and Bornman 1990; Ruaud et al. 1992; Ruaud 1993). Recently, Harvengt et al. (2001) indicated that embryogenic callus can be initiated from needles of 3-year-old somatic seedlings.

As a rule, during experiments on somatic embryogenesis in spruce, mature zygotic embryos were extracted directly after seed collection or after short-term storage. Frequency 
of embryogenic callus initiation varied depending on explant genotype, origin, developmental stage of embryos, seed storage duration, and culture conditions, which was also observed in this study. Von Arnold (1987) obtained embryogenic callus from $50 \%$ of Norway spruce mature zygotic embryos. Gupta and Durzan (1986) for zygotic embryos of Norway spruce (from seeds stored for 2 years) achieved callus from 5-6\% of explants, whereas Mala (1991) for embryos from seeds stored for 6 months produced embryogenic callus from $40-60 \%$ of explants.

Park et al. (1998), who conducted detailed genetic analyses during somatic embryogenesis of white spruce $(P$. glauca), found that the explant genotype has mainly influence on the first stage - embryogenic callus initiation. At later stages of somatic embryogenesis, the influence of genotype is weaker. Those authors pointed out also that the potential for embryogenic callus initiation declines in the course of seed ripening and their storage. The frequency of embryogenic tissue initiation was the highest $(56 \%)$ when explants were taken from freshly collected immature seeds and the lowest $(16 \%)$ when explants originated from mature embryos from stored seeds.

Many authors used immature zygotic embryos, which in our study were used mainly for micropropagation of hybrid larch and silver fir. Immature cones from plus trees and plantations are not easily available. In the case of this explant type, it is necessary to collect immature cones repeatedly (to obtain embryos at the precotyledonary stage), whereas cone collection from tree crowns is costly, difficult and its efficiency depends on weather conditions and cone yield. For forestry, it is more favourable to use mature zygotic embryos from seeds stored in cold rooms in forest seed banks. In this study, mature embryos showed high frequencies of embryogenic callus initiation in Norway spruce (up to $31.4 \%$ ) and Serbian spruce (up to $23.8 \%$ ), as compared to immature embryos (23\% and $10 \%$, respectively).

In larches, embryogenic callus was usually formed from immature zygotic embryos at an early stage of development (precotyledonary, 2 weeks after fertilization). Lelu et al. (1994a) recorded the highest frequency (19\%) of embryogenic tissue initiation in European larch when explants were at the precotyledonary stage, and the lowest (4\%) when embryos had big cotyledons. Similar results of culture initiation were recorded also for hybrid larch $(L . \times$ leptoeuropaea) and Japanese larch (L. leptolepis) (Klimaszewska 1989; von Aderkas et al. 1990; Lelu et al. 1994a). In comparison with those results, the frequencies of embryogenic callus initiation from larch megagametophytes with immature embryos in the present study (up to $35 \%$ ) are satisfactory. Because of the difficulty to obtain immature embryos at the appropriate developmental stage, we also used mature zygotic embryos as explants. Despite many attempts, no embryogenic callus from such embryos was initiated (Szczygieł 2005).

The available published data indicate that in the case of fir, the main sources of explants are immature zygotic embryos (Schuller et al. 1989; Salajova et al. 1992; Vookova et al. 1997/1998). Frequencies of callus initiation in European silver fir and its hybrids (Abies alba $\times$ A. cephalonica and $A$. alba $\times A$. nordmaniana) were the highest for embryos at early developmental stage (in July), whereas much lower values or even no initiation were observed for mature embryos (in August). In our study, we obtained a satisfac- tory frequency of embryogenic callus initiation in silver fir $(10.4 \%)$ for immature embryos at the cotyledonary stage (collected in late August). Much more favourable is the possibility to use mature zygotic embryos for embryogenic tissue initiation from mature zygotic embryos isolated from seeds stored in cold room. Good results of embryogenic callus initiation (29-40\%) from mature embryos of silver fir (Hristoforoglu et al. 1995; Szczygieł and Kowalczyk 2001), Caucasian fir (A. nordmaniana) and fir hybrids (A. alba $\times$ A. cephalonica) were reported by Norgaard and Krogstrup (1995) and Salajova (after Jasik et al. 1999). In our study, we also achieved a high frequency (about 30\%) of embryogenic callus initiation in silver fir from mature embryos kept in a cold store for more than 12 months.

The possibility of utilization of somatic embryos (at the globular or cotyledonary stage) and 1-month-old somatic seedlings (cotyledons or hypocotyls) of spruces and larches for initiation of secondary and third generation of embryogenic callus indicates a great efficiency of this method of micropropagation. In this study, the highest frequencies (40-80\%) of embryogenic callus initiation were recorded with the use of somatic embryos developed on secondary generation of embryogenic callus, as explants in larches.

For initiation of embryogenic callus on explants of all spruce and larch species are generally used the basal medium supplemented with an auxin $(9 \mu \mathrm{M} 2.4-\mathrm{D})$ and a cytokinin (4.4 $\mu \mathrm{M}$ BAP) (Hakman et al. 1985; Becwar et al. 1987; Bozhkov and von Arnold 1998; Filonova et al. 2000a). In this experiment, those hormones also usually proved to be sufficient for embryogenic callus initiation in those species.

In contrast to spruces and larches, which need the addition of an auxin and cytokinin to initiate embryogenic callus, in silver fir it is sufficient to add only a cytokinin. Usually $4.4 \mu \mathrm{M}$ BAP is used for initiation of somatic embryogenesis in fir (Schuller et al. 1989; Norgaard and Krogstrup 1995), but in this study we used $2.2 \mu \mathrm{M}$ BAP and 2.3 $\mu \mathrm{M}$ kinetin.

\section{Proliferation of embryogenic callus}

Embryogenic lines derived from individual explants (mainly immature and mature embryos) are characterized by varied dynamics of callus growth. Salopek et al. (1997) succeeded to produce 127 embryogenic lines of Serbian spruce but only 10 of the lines proliferated. Mo and von Arnold (1991) showed that only 5-15\% embryogenic lines of Norway spruce continued to grow, whereas Webb et al. (1989) reported that $50-75 \%$ of embryogenic cultures of white spruce died after a few months of culture.

In this study, embryogenic tissues of individual conifer taxa also differed in survival rate and ability to proliferate. The highest survival rate was observed in embryogenic callus of Norway spruce. They were characterized by good growth even after several years of in vitro culture, whereas the other studied spruce species lost their viability already after a few months. Our study shows that prolonged callus culture contributes to changes in its embryogenic potential. This is reflected in a lowered ability to produce embryos and in structural disturbances (Stasolla et al. 2002).

Embryogenic tissues are usually proliferated on the same medium as that used for embryogenic callus initiation or with slightly lowered concentrations of hormones (Filonova et al. 2000a; von Aderkas et al. 2001; Stasolla et al. 2002). 
In our study, a remarkable improvement of embryogenic culture growth at this stage was observed when the medium for Norway spruce was modified by decreasing sucrose concentration from 30 to $20 \mathrm{~g} / \mathrm{l}$, while for Serbian and Colorado blue spruce by replacing the auxin 2.4-D with $9 \mu \mathrm{M}$ Pikloram.

\section{Maturation of somatic embryos}

In conifers micropropagation via somatic embryogenesis, the addition of ABA at the maturation stage of somatic embryos is necessary to obtain well developed embryos at cotyledonary stage (Becwar et al. 1987; Misra 1994; Vagner et al. 1998; Filonova et al. 2000a, b). ABA plays an important role during zygotic and somatic embryogenesis. In this study, spruce culture on a medium with $\mathrm{ABA}$ lasted 3-5 weeks. The duration of embryogenic tissue contact with ABA affects not only the number of formed embryos but also their later development (germination, conversion into plantlets and adaptation to ex vitro conditions). Treatment with $\mathrm{ABA}$ for 5 weeks is sufficient to stimulate development of Norway spruce embryos into mature forms (Filonova et al. 2000b; Bozhkov and von Arnold 1998; Hogberg et al. 2001). Our results show that in spruces the largest numbers of mature somatic embryos were developed if the basal medium was supplemented with 20-40 $\mathrm{MM}$ ABA and $1 \mu \mathrm{M}$ IBA and the cultures were kept in dim light (25-30 $\mu \mathrm{E} \mathrm{m} \mathrm{m}^{-2} \mathrm{~s}^{-1}$ ) for 5 weeks. In the case of fir, it was favourable to supplement the basal medium with $20 \mu \mathrm{M} \mathrm{ABA}$ and 1 $\mu \mathrm{M}$ IBA and to keep the cultures in darkness for 8-10 weeks. On the basis of our study, we could not determine unambiguously the optimum ABA concentration for all studied lines of larches. Nevertheless, a large number of somatic embryos (from first, secondary and third generation callus line) at the cotyledonary stage was obtained if they were cultured with $20-60 \mu \mathrm{M} \mathrm{ABA}$ and $1 \mu \mathrm{M}$ IBA for 4 weeks in dim light $\left(25-30 \mu \mathrm{E} \mathrm{m}^{-2} \mathrm{~s}^{-1}\right)$. Lelu et al. (1994b) and Gutman et al. (1996) reported that culture with 60 $\mu \mathrm{M}$ ABA results in proper development of somatic embryos of Larix $\times$ leptoeuropaea, and they are morphologically similar to zygotic embryos. Our results indicate that larch callus of line 7 (L. $\times$ leptoeuropaea 69.18 ) produced somatic embryos most efficiently (as compared to the other larch lines) if cultured with $60 \mu \mathrm{M} \mathrm{ABA}$ and $1 \mu \mathrm{M}$ IBA, for 3-4 weeks.

\section{Germination, conversion of somatic embryos}

into plantlets and adaptation to ex vitro conditions

The most effective medium for somatic embryos of spruces and fir germination was half strength MS medium supplemented with activated charcoal (5 g/l), while the MSG basal medium was the best for larches.

Somatic embryos developed more often hypocotyls than roots, which indicate poor synchronization of their development. Further experiments showed that partial drying of embryos of Norway spruce and silver fir for 3-4 weeks stimulated and increased their germination rate, as compared to the control (without drying). The partial drying treatment also resulted in more synchronous development of roots and shoots in 1-month-old somatic spruce plantlets and had significant influence on root and shoot length. The drying phase was also necessary to stimulate root formation in germinating somatic embryos of silver fir (Hristoforoglu et al. 1995). Somatic embryos of European and hybrid larch
(L. $\times$ leptoeuropaea $)$ showed high germination and conversion rates without the drying procedure.

The conversion of somatic embryos into plantlets was also affected by embryo age, i.e. duration of their contact with ABA. In this study, 4-week-old somatic embryos of the studied spruce seedlings showed the highest conversion rate. Lelu et al. (1994c) pointed out that duration of the ABA treatment affects conversion of somatic embryos of L. $\times$ leptoeuropaea. As many as $93 \%$ of 3-week-old embryos (line 69.18) were converted into plantlets, and prolongation of ABA treatment (to 4-5 weeks) caused a decline of their conversion rate to $74 \%$.

Acclimation of somatic larch seedlings was relatively easy. Somatic seedlings of both European larch (from Poland) and hybrid larch (callus lines from France) were characterized by a high adaptability to natural conditions and good growth already in the first growing season. By contrast, adaptation of spruce and fir seedlings to natural conditions proved to be difficult. They needed special care in the greenhouse, e.g. controlled air temperature, misting, and shading. It is also advisable to stimulate apical bud development by cooling somatic seedlings of spruce to 4 $-10^{\circ} \mathrm{C}$ while still on the agar media.

\section{CONCLUSIONS}

The present studies showed the opportunity on application of somatic embryogenesis for efficient propagation of coniferous trees. The optimized culture conditions and media for individual stages of somatic embryogenesis increased the efficiency of the presented micropropagation method. Application of modern methods of cultivation for seedling production will certainly improve the growth and development of somatic seedlings as well as their acclimation to natural conditions.

\section{LITERATURE CITED}

ADAMS G.W., DOIRON M.G., PARK Y.S. BONGA J.M., CHAREST P.J. 1994. Commercialization potential of somatic embryogenesis in black spruce tree improvement. For. Chron. 70, 5: 593-598.

BECWAR M.R., NOLAND T.L., WANN S.R. 1987. Somatic embryo development and plant regeneration from embryogenic Norway spruce callus. Tappi J. 70: 155-160.

BECWAR M.R., NAGMANI R., WANN S.R. 1990. Initiation of embryogenic cultures and somatic embryo development in loblolly pine (Pinus taeda). Can. J. For. Res. 20: 810-817.

BORNMAN C.H., JANSSON E. 1981. Regeneration of plants from conifer leaf, with special reference to Picea abies and $P i$ nus sylvestris. Colloque International sur la Culture In Vitro des Essances Forestieres. Fontaineblau, AFOCEL. Nangis. 41-53.

BOZHKOV P.V., VON ARNOLD S. 1998. Polyethylene glycol promotes maturation but inhibits further development of Picea abies somatic embryos. Physiol. Plant. 104: 211-224.

CHALUPA V. 1985. Somatic embryogenesis and plantlet regeneration from cultured immature and mature embryos of Picea abies (L.) Karst. Comm. Inst. For. Cech. 14: 57-63.

FILONOVA L.H., BOZHKOV P.V., VON ARNOLD S. 2000a. Developmental pathway of somatic embryogenesis in Picea abies as revealed by time-lapse tracking. J. Exp. Bot. 51: 249-264.

FILONOVA L.H., BOZHKOV P.V., BRUKHIN V.B., DANIEL G., ZHIVOTOVSKY B., VON ARNOLD S. 2000b. Two waves of programmed cell death occur during formation and de- 
velopment of somatic embryos in the gymnosperm, Norway spruce. J. Cell. Sci. 113: 4399-4411.

GUPTA P.K., DURZAN D.J. 1986. Plantlet regeneration via somatic embryogenesis from subcultured callus of mature embryos of Picea abies (Norway spruce). In Vitro Cell. Dev. Biol. 22: 685-688.

GUTMANN M., VON ADERKAS P., LABEL P., LELU M.A. 1996. Effects of abscisic acid on somatic embryo maturation of hybrid larch. J. Exp. Bot. 47, 305: 1905-1917.

HAKMAN I., FOWKE L.C., VON ARNOLD S., ERIKSSON T. 1985. The development of somatic embryos in tissue cultures initiated from immature embryos of Picea abies (Norway spruce). Plant Sci. 38: 53-59.

HARVENGT L., TRONTIN J.F., REYMOND I., CANLET., PAQUES M. 2001. Molecular evidence of true-to-type propagation of 3-year old Norway spruce through somatic embryogenesis. Planta 213, 5: 828-832.

HAZUBSKA T., SZCZYGIEL K. 2003. Induction of somatic embryogenesis in spruce: Picea omorika, $P$. pungens 'Glauca', $P$. breweriana and $P$. abies. Dendrobiology 50: 17-24.

HOGBERG K.A., BOZHKOV P.V., GRONROOS R., VON ARNOLD S. 2001. Critical factors affecting ex vitro performance of somatic embryo plants of Picea abies. Scand. J. For. Res. 16: 259-304.

HRISTOFOROGLU K., SCHMIDT J., BOLHAR-NORDENKAMPF H. 1995. Development and germination of Abies alba somatic embryos. Plant Cell Tiss. Org. Cult. 40: 277-284.

JASIK J., SALAJOVA T., KORMUTAK A., SALAJ J. 1999. Somatic embryogenesis in hybrid firs. In: Somatic Embryogenesis in Woody Plants. Jain S.M., Gupta P.K., Newton R.J. (eds). Kluwer Academic Publishers, Vol, 4, 505-523.

KLIMASZEWSKA K. 1989. Plantlet development from immature zygotic embryos of hybrid larch through somatic embryogenesis. Plant. Sci. 63: 95-103.

LELU M.A., BORNMAN C.H. 1990. Induction of somatic embryogenesis in excised cotyledons of Picea glauca and Picea mariana. Plant Physiol. Biochem. 28, 6: 785-791.

LELU M.A., BOULAY M., ARNAUD Y. 1987. Obtention de cals embryogènes à partir de cotylédons de Picea abies (L.) Karst. préléves sur de jeunes plantes âgées de 3 à 7 jours aprčs germination. C.R. Acad. Sci. Paris, Série 3, 305: 105-109.

LELU M.A., KLIMASZEWSKA K., CHAREST P.J. 1994a. Somatic embryogenesis from immature and mature zygotic embryos and from cotyledons and needles of somatic plantlets of Larix. Can. J. For. Res. 24: 100-106

LELU M.A., WARD C., BASTIEN C., KLIMASZEWSKA K., CHAREST P.J. 1994b. An improved method for somatic plantlet production in hybrid larch (Larix $\times$ leptoeuropaea): Part I. Somatic embryo maturation. Plant Cell Tiss. Org. Cult. 36: 107-115.

LELU M.A., BASTIEN K., MILLET N., CHAREST P.J. 1994c. An improved method for somatic plantlet production in hybrid larch (Larix $\times$ leptoeuropaea): Part II. Control of germination and plantlet development. Plant Cell Tiss. Org. Cult. 36: 117$-127$.

LITVAY J.D., VERMA D.C., JOHSON M.A. 1985. Influence of loblolly pine (Pinus taeda L.) culture medium and its components on growth and somatic embryogenesis of wild carrot (Daucus carota L.). Plant Cell Rep. 4: 325-328.

MALA J. 1991. Organogenesis and somatic embryogenesis in spruce (Picea abies (L.) Karst.). Comm. Inst. Forest Cech. 17: 59-72.

MISRA S. 1994. Conifer zygotic embryogenesis, somatic embryogenesis, and seed germination: Biochemical and molecular advances. Seed Sci. Res. 4: 357-384.

MO L.H., VON ARNOLD 1991. Origin and development of embryogenic cultures from seedlings of Norway spruce (Picea abies). J. Plant. Physiol. 138: 223-230.
MURASHIGE T., SKOOG F. 1962. A revised medium for rapid growth and bio-assays with tobacco tissue cultures. Physiol. Plant. 15: 473-497.

NORGAARD J.V., KROGSTRUP P. 1995. Somatic embryogenesis in Abies spp. In: Somatic Embryogenesis in Woody Plants. Jain S.M., Gupta P.K., Newton R.J. (eds). Kluwer Academic Publishers. Dordrecht. Vol. 3, 341-355.

PARK Y.S., BARRETT J.D., BONGA J.M. 1998. Application of somatic embryogenesis in high-value clonal forestry: deployment, genetic control, and stability of cryopreserved clones. In Vitro Cell. Develop. Biol. Plant. 34: 231-239.

ROBERTS D.R., SUTTON B.C.S., FLINN B.S. 1990. Synchronous and high frequency germination of interior spruce somatic embryos following partial drying at high relative humidity. Can. J. Bot. 68: 1086-1090.

RUAUD J.N. 1993. Maturation and conversion into plantlets of somatic embryos derived from needles and cotyledons of 7 56-day old Picea abies. Plant Sci. 92: 213-220.

RUAUD J.N, BERCETCHE J., PAQUES M. 1992. First evidence of somatic embryogenesis from needles of 1-year-old Picea abies plants. Plant Cell Rep. 11: 563-566.

SALAJOVA T., SALAJ J., KORMUTAK A. 1992. Induction of somatic embryogenesis in hybrid firs (Abies sp.). Biol. Plant. 34 (Suppl.): 547-548.

SALOPEK B., TRAMISAK-MILAKOVIĆ T., MIHALJEVIĆ S., JELASKA S. 1997. Storage productaccumulation during the maturation of Picea omorika (Panc.) Purk. somatic embryos. Period. Biol. 99 (1): 117-124.

SCHENCK R.U., HILDEBRANDT A.C. 1972. Medium and techniques for induction and growth of monocotyledonous and dicotyledonous plant cell cultures. Can. J. Bot. 50: 199-204.

SCHULLER A., REUTHER G., GEIER T. 1989. Somatic embryogenesis from seed explants of Abies alba. Plant Cell Tiss. Org. Cult. 17: 53-58.

STASOLLA C., KONG L., YEUNG E.C., THORPE T.A. 2002. Maturation of somatic embryos in conifers: morphogenesis, physiology, biochemistry and molecular biology. In Vitro Cell. Dev. Biol. Plant 38: 93-105.

SZCZYGIEŁ K. 2005. Mikrorozmnażanie modrzewia europejskiego (Larix Decidua Mill.) metodą somatycznej embriogenezy. Leśne Prace Badawcze. 4: 47-76. (in Polish)

SZCZYGIEŁ K., KOWALCZYK J. 2001. Somatic embryogenesis of Silver fir (Abies alba Mill.) - Polish provenances. Proceedings of the Fourth International Symposium on In Vitro Culture and Horticultural Breeding. Tampere, Finlandia. Acta Hort. 560: 509-512.

VAGNER M., VONDRAKOVA Z., STRRNADOVA Z., EDER J., MACHACKOVA I. 1998. Endogenous levels of plant growth hormones during early stages of somatic embryogenesis of Picea abies. Adv. Hort. Sci. 12: 11-18.

VON ADERKAS P., KLIMASZEWSKA K., BONGA J. 1990. Diploid and haploid embryogenesis in Larix leptolepis, L. decidua, and their reciprocal hybrids. Can. J. For. Res. Vol. 20: 9-14.

VON ADERKAS P., LELU M.A., LABEL P. 2001. Plant growth regulator levels during maturation of larch somatic embryos. Plant Physiol. Biochem. Edision scientifiques et medicales Elsevier SAS. 39: 495-502.

VON ARNOLD S. 1987. Improved efficiency of somatic embryogenesis in mature embryos of Picea abies (L.) Karst. J. Plant Physiol. 128: 233-244.

VOOKOVA B., GAJDOSOVA A., MATUSOVA R. 1997/1998. Somatic embryogenesis in Abies $\times$ Abies alba and Abies alba $\times$ Abies nordmanniana hybrids. Biol. Plant. 40 (4): 523-530.

WEBB D.T., WEBSTER F., FLINN B.S., ROBERTS D.R., ELLIS D.D. 1989. Factors influencing the induction of embryogenic and caulogenic callus from embryos of Picea glauca and P. engelmanii. Can. J. For. Res. 19: 1303-1308. 